\title{
Proteomic analysis of Cucumis sativus cotyledons after glucohexaose treatment as a part of ROS accumulation related resistance mechanism
}

\author{
Yuhan Hao ${ }^{1,3}$, Chunmei Lin ${ }^{1}$, Haiyan Fan ${ }^{1,2^{*}}$, Yang Yu', Ning Li ${ }^{1}$ and Shaoli Chen ${ }^{4}$
}

\begin{abstract}
Background: Glucohexaose is a safe farm chemical used for pathogen prevention, which can induce systemic acquired resistance in cucumber.

Results: We found that glucohexaose treatment of cucumber plant induced an accumulation of the reactive oxidative species (ROS). Histochemistry showed sharp increases in $\mathrm{O}^{2-}$ and $\mathrm{H}_{2} \mathrm{O}_{2} 5 \mathrm{~h}$ after glucohexaose treatment. After $5 \mathrm{~h}$, the $\mathrm{O}^{2-}$ content decreased to a normal level, but the $\mathrm{H}_{2} \mathrm{O}_{2}$ content remained at a high level $10 \mathrm{~h}$ after glucohexaose treatment. And antioxidant enzymes were also changed after glucohexaose treatment. We also investigated the relationship between ROS accumulation and glucohexaose-induced proteome alteration using 2D electrophoresis coupled with MS/MS. 54 protein spots, which enhanced expression under glucohexaose treatment but suppressed the expression by application of DPI and DMTU, have been identified.

Conclusion: Our study showed the accumulation of ROS is a part of mechanism of glucohexaose induced resistance in cucumber cotyledons. The up-regulated proteins identified by MS such as PP2C and antioxidation proteins are important in ROS signaling. It will be interesting to find out the regulatory mechanism underlying the induction of these proteins via ROS, and provide some clues to the mechanism of glucohexaose-induced resistance.
\end{abstract}

Keywords: Cucumis sativus, Glucohexaose, Reactive oxygen species, Proteome

\section{Introduction}

During vegetable production, chemical pesticides are still the main method of disease prevention. As consumers' concerns about food quality increase, how to prevent disease without pesticide residues has attracted more attention. Induced resistance by biotic and abiotic elicitors is a new method for disease resistance. Glucohexaose, synthesized by the Research Center for Eco-Environmental Science, Chinese Academy of Science, is a safe, synthetic oligosaccharide elicitor that is naturally degraded in the environment. After glucohexaose incubation, plant resistance systems were activated and plants acquired stronger resistance to many pathogens, such as Pseudoperonospora cubensis [1]. Using glucohexaose in agricultural production

\footnotetext{
*Correspondence: hyfan74@163.com

'College of Bioscience and Biotechnology, Shenyang Agricultural University, Shenyang 110866, PR China

${ }^{2}$ Key Laboratory of Protected Horticulture of Ministry of Education, Shenyang Agricultural University, Shenyang 110866, PR China

Full list of author information is available at the end of the article
}

would be a safer and more acceptable alternative to chemical pesticides. However, the mechanism of the induced resistance remains unclear. A previous proteomic study in our laboratory using cucumber leaves after glucohexaose treatment identified certain ROS accumulation related proteins [2], which indicated that the ROS accumulation might be one of the mechanisms of glucohexaose-induced resistance.

ROS, including superoxide $\left(\mathrm{O}^{2-}\right)$, hydrogen peroxide $\left(\mathrm{H}_{2} \mathrm{O}_{2}\right)$, hydroxyl radical $(\mathrm{OH} \cdot)$ and singlet oxygen $\left({ }^{1} \mathrm{O}_{2}\right)$, play an important role in resistance to pathogens as signal molecules in plant cells [3]. The oxidative burst (OXB) was first reported by Doke in 1983 in a study of the interaction between potato tuber tissues and Phytophthora infestan [4], which involves the rapid release of ROS in the early stage of pathogen infection. Later studies indicated that in many stress conditions, such as bacterial, viral and fungal infection, the induction of elicitors and the composition of the cell wall, and mechanical stress could lead to the rapid release of ROS $[5,6]$. 
The main ROS in plant cells is $\mathrm{H}_{2} \mathrm{O}_{2}$, which can be transported across cell membranes to act as a signal molecule and is an essential signaling mediator of plant stress resistance [7-9]. There are different ROS generating mechanisms in different plants, such as germin-like oxalate oxidase, polyamine oxidase, peroxidase, thioredoxins and glutaredoxins [10-16]. However, in most plants, NADPH oxidase is the principal source of ROS induced by pathogens or elicitors $[17,18]$. NADPH oxidase, located in the cell membrane, is a redox enzyme containing a heme moiety and six transmembrane domains. It transfers an electron from $\mathrm{NADPH}$ to $\mathrm{O}_{2}$, and generates large amounts of $\mathrm{O}^{2-}$ in a short time [18].

Proteomic study is a good tool to investigate the mechanism of ROS related glucohexaose induced resistance. It is used in other stress related ROS pathway studies in different species. Soares, et al. investigated wound related proteome changes in ROS pathway in Medicago and found some interesting proteins such as SODs, peroxidases and germin-like proteins [19]. Wang, et al. found AtCIAPIN1 and flg22 are earlyresponsive redox-sensitive proteins in Arabidopsis with proteomic studies [20]. In wheat, Bykova, et al. reported several redox-sensitive proteins functioning in seed dormancy control [21]. Therefore, we sought to use proteomic tool to further investigate the possible link between glucohexaose-induced resistance and ROS accumulation. We report that glucohexaose can induce ROS accumulation in cucumber cotyledons and provide some clues concerning the mechanism of glucohexaoseinduced ROS accumulation. These results provide a theoretical basis for developing safe farm chemicals for vegetable production.

\section{Materials and methods}

\section{Plant materials}

Cucumber seeds (Jinyan No. 4) were soaked in water for $24 \mathrm{~h}$ and then sterilized with $75 \%$ ethanol for $30 \mathrm{~s}$ and $2.5 \% \mathrm{NaClO}$ for $15 \mathrm{~min}$. After washing with sterile water at least three times, sterilized seeds were placed on sterile water soaked gauze. The seeds were allowed to germinate at $25-30^{\circ} \mathrm{C}$. When the cotyledons expanded, the seedlings were used for subsequent experiments.

\section{The detection of variation of $\mathrm{H}_{2} \mathrm{O}_{2}$ and $\mathrm{O}^{2-}$ in glucohexaose-treated cotyledons}

Whole plants were sprayed with $50 \mu \mathrm{g} / \mathrm{ml}$ glucohexaose and $\mathrm{H}_{2} \mathrm{O}_{2}$ and $\mathrm{O}^{2-}$ were detected at $1,2,3,4,5,6,7,8$, $9,10,11,12,13,14$ and $15 \mathrm{~h}$ after glucohexaose treatment. We detected $\mathrm{H}_{2} \mathrm{O}_{2}$ and $\mathrm{O}^{2-}$ using DAB and NBT staining methods, according to Zhang et al. [22] and Soares et al. [19] with modifications. Cucumber cotyledons were soaked with $1 \mathrm{mg} / \mathrm{ml}$ DAB (Sigma, St. Louis, $\mathrm{MO}$, USA) for $8 \mathrm{~h}$ and infiltrated with $0.1 \% \mathrm{NBT}$
(Ameresco, OH, USA) for $20 \mathrm{~min}$, respectively. The cotyledons were then transferred to $95 \%$ ethanol in an $80^{\circ} \mathrm{C}$ water bath. After the green color of the cotyledons disappeared, the cotyledons were photographed to show the variation of $\mathrm{H}_{2} \mathrm{O}_{2}$ and $\mathrm{O}^{2-}$. Cotyledons were preserved in $95 \%$ ethanol at $4{ }^{\circ} \mathrm{C}$. Three independent replicates preformed for each assay.

To investigate the effect of DPI (an inhibitor of NADPH oxidase) and DMTU (a ROS scavenger) during the oxidative burst, we treated two groups of plants with glucohexaose after incubating them with $100 \mu \mathrm{M}$ DPI and $5 \mathrm{mM}$ DMTU for $4 \mathrm{~h}$.

\section{Determination of scavenger enzymes activity}

Assay kits (Nanjing Jiancheng Bioengineering Institute, China) were used to measure SOD activity, MDA contents, POD activity, CAT activity, APX activity and GPX activity.

\section{Protein extraction}

Proteins were extracted with a PEG precipitation method according to $\mathrm{Xi}$ et al. [23], with modifications. Cucumber cotyledons were collected and pulverized to a fine powder with liquid nitrogen. The finely ground powder was extracted with $\mathrm{Mg} / \mathrm{NP}-40$ extraction buffer containing $0.5 \mathrm{M}$ Tris- $\mathrm{HCl}(\mathrm{pH} 8.3), 2 \%(\mathrm{v} / \mathrm{v}) \mathrm{NP}-40$, $20 \mathrm{mM} \mathrm{MgCl} 2,2 \%$ (v/v) $\beta$-mercaptoethanol, $1 \mathrm{mM}$ PMSF, $1 \%(\mathrm{w} / \mathrm{v})$ PVP and $1 \mathrm{mM}$ EDTA. After centrifugation at $13000 \times \mathrm{g}$ for $15 \mathrm{~min}$, the supernatant was precipitated with 50\% PEG stock solution to adjust the final PEG concentration to $24 \%$, which is the appropriate PEG concentration for cucumber Rubisco protein precipitation. After centrifugation at $13000 \times \mathrm{g}$ for $30 \mathrm{~min}$, the pellet was named as fraction F1 and the supernatant was precipitated with $10 \%$ (TCA)/acetone solution at $-20^{\circ} \mathrm{C}$ for at least $1 \mathrm{~h}$. The TCA/acetone precipitation fraction was centrifuged at $13000 \times \mathrm{g}$ for $30 \mathrm{~min}$ and the pellet named as fraction F2. The F1 and F2 pellets were washed with TCA/acetone until they were colorless, and then they were washed three times with $80 \%$ acetone containing $0.07 \% \beta$-mercaptoethanol. Proteins were freeze-dried and stored at $-80^{\circ} \mathrm{C}$ for subsequent tests.

\section{2-D electrophoresis}

The dried proteins were redissolved in lysis buffer containing $8 \mathrm{M}$ Urea, $2 \mathrm{M}$ Thiourea, $4 \%$ CHAPS, 1\% DTT, $1 \%$ TBP and $2 \%$ IPG buffer for $3-4 \mathrm{~h}$ at $30^{\circ} \mathrm{C}$. The samples were centrifuged at $12000 \times \mathrm{g}$ for $10 \mathrm{~min}$ at room temperature and the pellet was discarded. The supernatant was tested by the Bradford method to determine the protein content and loaded onto $24 \mathrm{~cm} \mathrm{pH} \mathrm{4-7} \mathrm{IPG}$ stripes with $1 \mathrm{mg}$ and $450 \mu \mathrm{l}$ protein solution. The IEF conditions were as follows: $50 \mathrm{~V}$ for $15 \mathrm{~h}, 100 \mathrm{~V}$ for $1 \mathrm{~h}$, $250 \mathrm{~V}$ for $3 \mathrm{~h}, 500 \mathrm{~V}$ for $3 \mathrm{~h}, 1000 \mathrm{~V}$ for $1 \mathrm{~h}, 10000 \mathrm{~V}$ for 
$3 \mathrm{~h}, 10000 \mathrm{~V}$ for $160000 \mathrm{Vh}$ and $500 \mathrm{~V}$ thereafter (Ettan IPGphorIII, GE Healthcare). After IEF, the focused strips were equilibrated with equilibration solutions twice. $2 \%$ DTT and 2.5\% iodoacetamide were added to equilibration mother solution, which contained $6 \mathrm{M}$ Urea, $0.05 \mathrm{M} \mathrm{pH} 8.8$ Tris-HCl, 2\% SDS and 20\% glycerol. The second dimension SDS-PAGE was performed on an Ettan DALT six (GE Healthcare) with an $11 \%$ polyacrylamide gel. CBB R350 was used to stain the 2D gels, according to the operation manual (GE Healthcare).

\section{Image analysis}

A UMAX Power Look 2100XL (Maxium Tech., Taipei, China) was used to scan the 2D gels in TIF images. The spots are then analyzed by PDQuest Advanced $^{\text {Tx }}$ 2-D Analysis software (version 8.0.1, Bio-Rad). Each image was adjusted to be the same size and the Spot Detection Parameter Wizard was used to automatically pair the spots on each image. Landmarks and manual matching helped the accuracy of the pairing. Quantitative analysis was performed by Student's test only for notable spots in groups of three biological replicated gels. Protein spots selected for future identification showed an increase of at least 2.0-fold in the $\mathrm{P}$ group compared with the CK group, and at the same time the DPI and DMTU group were decreased relative to the $\mathrm{P}$ group. Here, CK represents the control group and $\mathrm{P}$ represents the cucumber cotyledons treated with $50 \mu \mathrm{g} / \mathrm{ml}$ glucohexaose for $5 \mathrm{~h}$. The DPI and DMTU groups represent those treated with DPI and DMTU for $4 \mathrm{~h}$ before $50 \mu \mathrm{g} / \mathrm{ml}$ glucohexaose treatment.

\section{Protein identification by MS}

The selected spots were excised from gels using pipette tips, placed in tubes and decolored using 200-400 $\mu \mathrm{l}$ $100 \mathrm{mM} \mathrm{NH} \mathrm{HCO}_{3} / 30 \% \mathrm{ACN}$. After freeze-drying, the protein spots were digested by trypsin (the ratio of trypsin to proteins was 1:20-1:100) for approximately $20 \mathrm{~h}$ at $37^{\circ} \mathrm{C}$. The hydrolysates were then transferred to new tubes and disrupted by sonication for $15 \mathrm{~min}$ in a buffer containing $100 \mu \mathrm{l} 60 \% \mathrm{ACN} / 0.1 \%$ TFA and desalinated in a Ziptip (Millipore). The in-gel digested proteins were freeze-dried and resolved by $2 \mu \mathrm{l} 20 \% \mathrm{ACN}$ for each $1 \mu \mathrm{l}$ of protein. After air-drying, $0.5 \mu \mathrm{l}$ of over-saturated CHCA solution was added (dissolved in $50 \% \mathrm{ACN}$ and $0.1 \%$ TFA) and the proteins were then air-dried. A 4800 Plus MALDI TOF/TOFTM Analyzer (Applied Biosystems, USA) was used for MS analysis with the Nd:YAG lasing light emitter, $2 \mathrm{kV}$ voltage, positive ion model, 800-4000 Da PMF quality scan range. MS/MS analysis was performed with parent irons with signal to noise ratios of more than 50, and excited 2500 times by the MS/ MS laser with a collision energy of $2 \mathrm{kV}$ and CID closure. For database searching, the conditions were set as follows: database: IPI, taxonomy: Viridiplantae (900091), type of search: Peptide Mass Fingerprint (MS/MS Ion Search), enzyme: Trypsin, Fixed modifications: Carbamidomethyl (C), mass values: Monoisotopic, protein mass: Unrestricted, peptide mass tolerance: $\pm 100 \mathrm{ppm}$, fragment mass tolerance: $\pm 0.8 \mathrm{Da}$, peptide charge state: $1+$ and max missed cleavages: 1 .

\section{Results}

\section{Glucohexaose-induced ROS accumulation}

To determine whether glucohexaose can actually induce an ROS accumulation in cucumber cells and when the accumulation occurs, we detected two ROS, $\mathrm{H}_{2} \mathrm{O}_{2}$ and $\mathrm{O}^{2-}$, using DAB and NBT staining at $1,2,3,4,5,6,7,8$, $9,10,11,12,13,14$ and $15 \mathrm{~h}$ after glucohexaose treatment. $\mathrm{H}_{2} \mathrm{O}_{2}$ and $\mathrm{O}^{2-}$ began to accumulate after glucohexaose treatment and peaked at $5 \mathrm{~h}$ after treatment (Figure $1 \mathrm{~A}$ and $\mathrm{B}$ ). After incubated with the inhibitor of NADPH oxidase DPI and the ROS scavenger DMTU before glucohexaose treatment, ROS failed to accumulate (Figure $1 \mathrm{C}$ and $\mathrm{D}$ ). Antioxidant enzymes were also changed after glucohexaose treatment. SOD activity indicated $\mathrm{O}^{2-}$ level increased after glucohexaose treatment (Figure 1E). As a main signaling messenger, $\mathrm{H}_{2} \mathrm{O}_{2}$ scavengers behaved differently: POD and APX activities increased and CAT and GPX activities decreased after glucohexaose treatment (Figure 2E-J). The different responses of the four $\mathrm{H}_{2} \mathrm{O}_{2}$ scavengers indicated a complicated mechanism of $\mathrm{H}_{2} \mathrm{O}_{2}$ regulation in the plant cells. Moreover, SOD, CAT, POD, APX and GPX activity returned to the control level after DPI and DMTU incubation. These results showed that ROS accumulated at $5 \mathrm{~h}$ after glucohexaose treatment. As ROS accumulation is an important part of plant immune action, it is also a part of mechanism of glucohexaose induced cucumber resistance.

\section{Proteomic analysis of cucumber cotyledons after ROS accumulation induced by glucohexaose}

Because $\mathrm{H}_{2} \mathrm{O}_{2}$ and $\mathrm{O}^{2-}$ showed sharp increases at $5 \mathrm{~h}$ after glucohexaose treatment, however, DMTU or DPI pretreatment significantly abolished the effect of glucohexaose. To find out the regulatory mechanism underlying the induction of proteins via ROS, four samples were applied to 2-DE analysis. At first, sample 1 and 2 were sprayed with deionized water, sample 3 and 4 were pretreated with $5 \mu \mathrm{M}$ DMTU and $100 \mu \mathrm{M}$ DPI, respectively. After $4 \mathrm{~h}$ of pretreatment, deionized water was used to spray sample 1 (control plants), sample 2, 3, 4 were sprayed with $50 \mu \mathrm{g} / \mathrm{ml}$ glucohexaose. Then, at $5 \mathrm{~h}$ after last treatment, the cucumber cotyledons were harvested.

Total proteins extracted from cucumber cotyledons were divided into two fractions, F1 and F2, using the PEG precipitation method. After 2D electrophoresis 
A
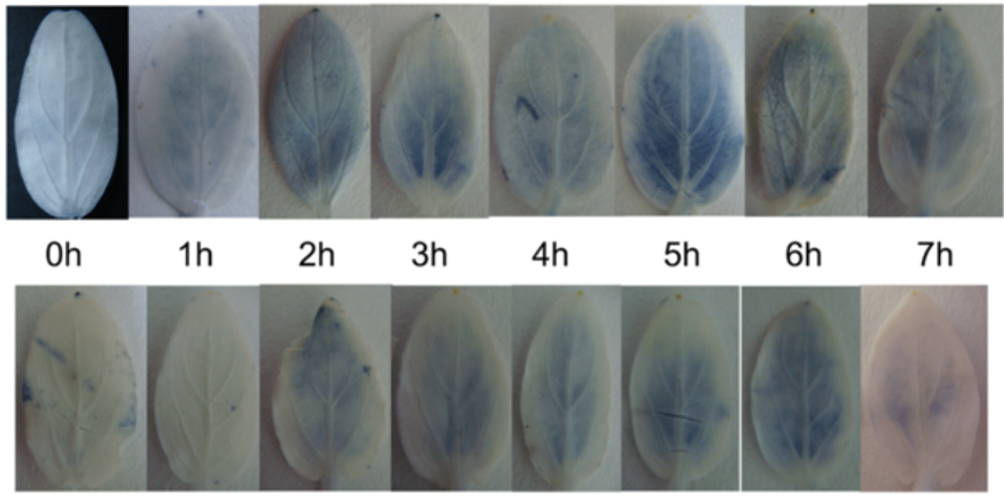

$8 \mathrm{~h} \quad 9 \mathrm{~h} \quad 10 \mathrm{~h} \quad 11 \mathrm{~h} \quad 12 \mathrm{~h} \quad 13 \mathrm{~h} \quad 14 \mathrm{~h} \quad 15 \mathrm{~h}$

B
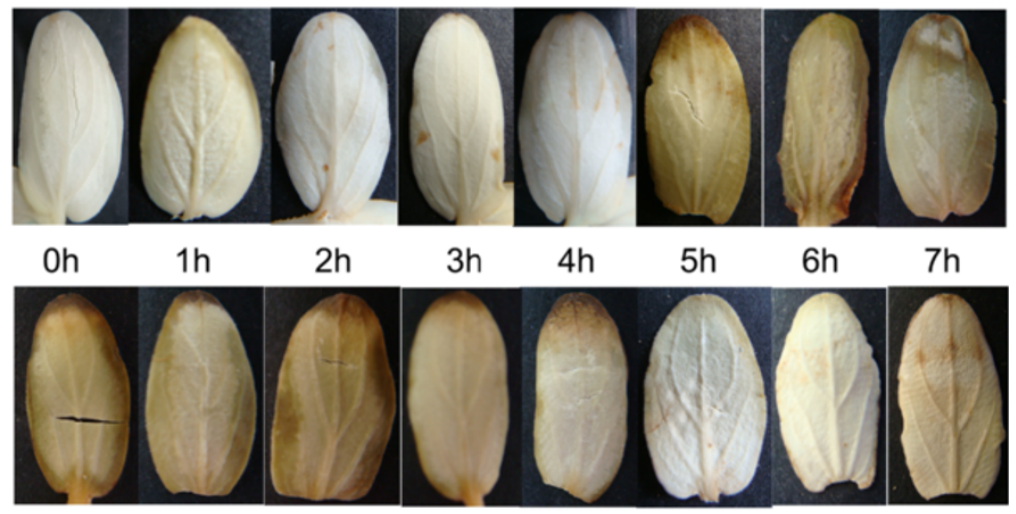

$8 \mathrm{~h} \quad 9 \mathrm{~h} \quad 10 \mathrm{~h} \quad 11 \mathrm{~h} \quad 12 \mathrm{~h} \quad 13 \mathrm{~h} \quad 14 \mathrm{~h} \quad 15 \mathrm{~h}$

C

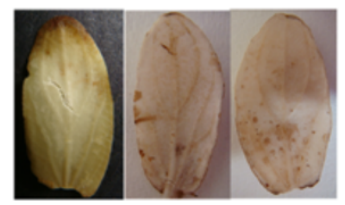

5h DPI DMTU

E

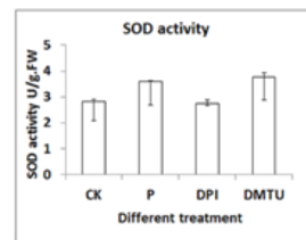

$\mathrm{F}$

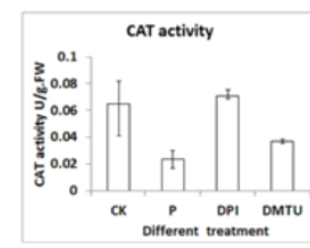

$\mathrm{H}$
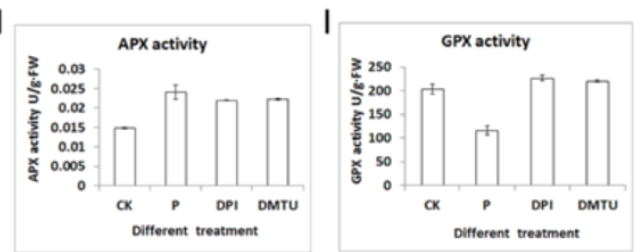

D

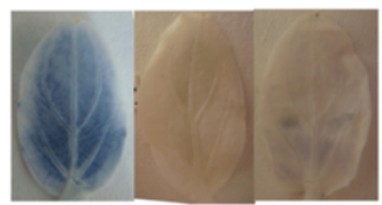

5h DPI DMTU

G
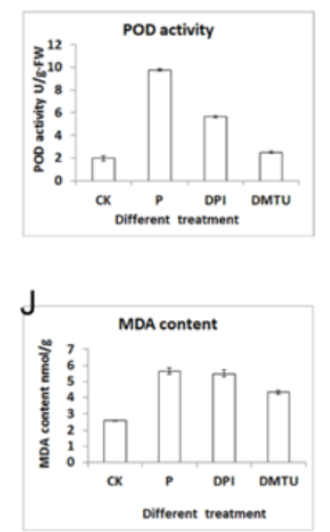

Figure 1 (See legend on next page.) 
(See figure on previous page.)

Figure 1 Glucohexaose can induce ROS accumulation. A-B. Changes of $\mathrm{O}^{2-}(\mathbf{A})$ and $\mathrm{H}_{2} \mathrm{O}_{2}$ (B) after treatment of glucohexaose. Cucumber cotyledons are infiltration with $0.1 \% \mathrm{NBT}$ and $1 \mathrm{mg} / \mathrm{mL}$ DAB and decolourisation. One to fifteen hours after glucohexaose treatment indicated the plants' early respond to glucohexaose. C-D. DPI and DMTU incubation can eliminate the ROS accumulation at five hours after glucohexaose treatment. E-J. Some important ROS scavenging enzymes activity in cucumber cotyledons with different treatment. CK represent the control group; P represent the cucumber cotyledons treated with $50 \mu \mathrm{g} / \mathrm{mL}$ glucohexaose for five hours; DPI and DMTU represent before treated with $50 \mu \mathrm{g} / \mathrm{mL}$ glucohexaose, DPI and DMTU were incubated for four hours. Error bar represent SD.

and image analysis by MS, we identified 55 protein spots that showed significant expression changes. Fiftyfour protein spots (Figure 2, Additional file 1: Figure S1 and Additional file 1: Figure S2) corresponding to 37 proteins were identified by MALDI-TOF-TOF MS (Table 1). The protein spots chosen showed increased abundance after glucohexaose treatment and decreased when incubated with DPI or DMTU; therefore, they are possibly related to the glucohexaose induced ROS accumulation. After data analysis, sequence alignment, GO annotation and reference searching, we divided these proteins into eight groups: photosynthesis-related proteins, respiration and metabolism-related proteins, translation-related proteins, proteolytic enzymes, protein phosphatases, antioxidation proteins and unclassified proteins. Each group may play an important role in glucohexaose induced ROS accumulation.

\section{ROS-related proteins identified by MALDI-TOF-TOF MS}

NADPH oxidase, which transfers an electron from NADPH to $\mathrm{O}_{2}$ is the principal source of ROS in a short time. In animal cells, the pentose phosphate pathway is the main source of NADPH accumulation [24]. In plant cells, the large amount of NADPH generates from both photosynthesis and pentose phosphate pathway [25]. In this study, we have identified the increase of several
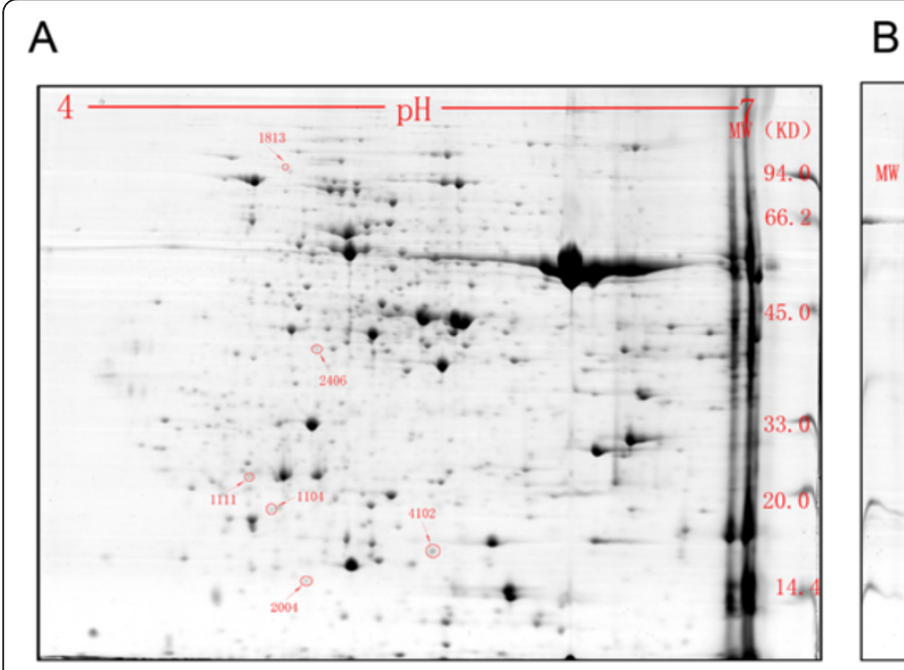

B
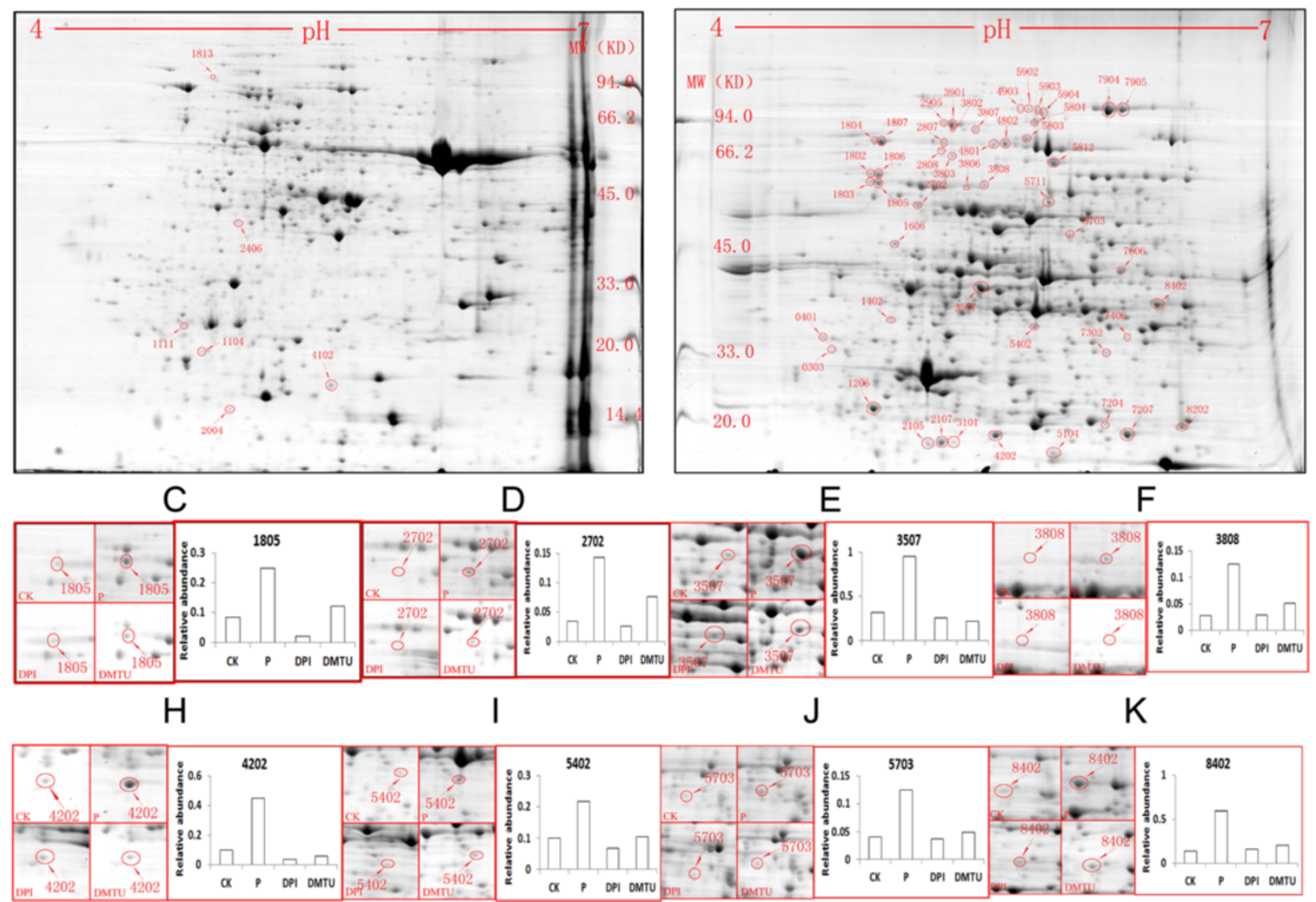

Figure 2 Proteomic analysis of glucohexaose induced ROS accumulation. A-B 2D maps of identified differential expression cucumber cotyledon proteins spots. These two maps are from the P group and other groups' picture offered in supplemental materials. $\mathbf{C}-\mathbf{K}$ Representative differential protein spots and their relative abundance. All identified protein spots' information is supplied in supplemental materials. 
Table 1 Glucohxaose and ROS modulators-regulated proteins

\begin{tabular}{|c|c|c|c|c|c|c|c|c|c|c|}
\hline ID & gi & Protein name & PI & MW & $\begin{array}{l}\text { Protein } \\
\text { score }\end{array}$ & $\begin{array}{l}\text { Protein } \\
\text { score C.I. } \%\end{array}$ & $\begin{array}{l}\text { Pep. } \\
\text { count }\end{array}$ & E-value & $\begin{array}{c}\text { Fold enhancement } \\
\text { by P6 }\end{array}$ & $\begin{array}{c}\text { Percentage of suppression } \\
\text { by DPI/DMTU }\end{array}$ \\
\hline \multicolumn{11}{|c|}{ Photosynthesis related proteins } \\
\hline 1104 & gi|12620881 & $\begin{array}{l}\text { Ribulose-1,5-bisphosphate } \\
\text { carboxylase/oxygenase activase }\end{array}$ & 5.54 & 48186.1 & 284 & 100 & 9 & & 1.68 & $84.15 / 61.03$ \\
\hline 1111 & gi|115768 & $\begin{array}{c}\text { Chlorophyll a-b binding protein } \\
\text { of LHCII type I }\end{array}$ & 5.14 & 27331.7 & 282 & 100 & 7 & & 2.05 & $69.18 / 52.48$ \\
\hline 2004 & gi|325515965 & $\begin{array}{l}\text { Ribulose-1,5-bisphosphate } \\
\text { carboxylase/oxygenase large subunit }\end{array}$ & 6.67 & 23461.8 & 651 & 100 & 12 & & 7.76 & $50.81 / 24.37$ \\
\hline 4102 & gi|255567170 & Chlorophyll A/B binding protein & 6.85 & 29362 & 82 & 99.482 & 5 & & 1.40 & $82.39 / 55.08$ \\
\hline 0401 & gi|62899808 & $\begin{array}{l}\text { Chromoplast-specific } \\
\text { carotenoid-associated protein }\end{array}$ & 5.05 & 35272.5 & 581 & 100 & 16 & & 11.35 & $86.13 / 83.53$ \\
\hline 3507 & gi|125578 & Phosphoribulokinase & 6.03 & 44485.6 & 552 & 100 & 12 & & 2.97 & $73.35 / 77.00$ \\
\hline 3806 & gi|12585325 & Phosphoglucomutase & 5.56 & 68625.8 & 322 & 100 & 8 & & 2.36 & $48.99 / 41.42$ \\
\hline 5104 & gi|11134156 & Oxygen-evolving enhancer protein 2 & 8.61 & 28292.3 & 786 & 100 & 12 & & 2.57 & $17.35 / 36.94$ \\
\hline \multicolumn{11}{|c|}{ Metabolism-related proteins } \\
\hline 1206 & gi|225451299 & Ribose-5-phosphate isomerase & 6.66 & 30340.1 & 291 & 100 & 7 & & 1.58 & $49.04 / 61.65$ \\
\hline 1606 & gi|147838694 & Chloroplast fructose-1,6-bisphosphatase & 5.3 & 45183.4 & 898 & 100 & 11 & & 3.55 & $88.59 / 33.13$ \\
\hline 2406 & gi|3328122 & Phosphoglycerate kinase precursor & 7.68 & 50594 & 449 & 100 & 9 & & 1.87 & $57.87 / 50.11$ \\
\hline 2702 & gi|118721470 & Vacuolar $\mathrm{H}+-$ ATPase subunit B & 5.18 & 54450.9 & 575 & 100 & 17 & & 4.21 & $81.96 / 47.07$ \\
\hline 5402 & gi|307136265 & Fructokinase & 5.61 & 35800.6 & 403 & 100 & 16 & & 2.15 & $68.33 / 52.23$ \\
\hline 7207 & gi| 2833386 & Ribulose-phosphate 3-epimerase & 8.23 & 30632.2 & 299 & 100 & 5 & & 9.18 & $79.61 / 78.13$ \\
\hline 7904 & gi|1351856 & Aconitate hydratase & 5.74 & 98569.8 & 884 & 100 & 23 & & 3.60 & $90.35 / 74.12$ \\
\hline 7905 & gi|1351856 & Aconitate hydratase & 5.74 & 98569.8 & 1070 & 100 & 26 & & 7.19 & $91.27 / 76.31$ \\
\hline 8402 & gi|255557204 & Fructose-bisphosphate aldolase, putative & 7.59 & 38745.2 & 121 & 100 & 3 & & 4.44 & $73.13 / 66.04$ \\
\hline \multicolumn{11}{|c|}{ Chaperones and elongation factors } \\
\hline 1813 & gi|225445166 & Elongation factor ts & 4.78 & 123315.5 & 110 & 100 & 6 & & 7.76 & $53.68 / 63.39$ \\
\hline 1804 & gi|124245039 & Chloroplast HSP70 & 5.18 & 75464.1 & 1070 & 100 & 28 & & 15.05 & $99.55 / 86.18$ \\
\hline 1807 & gi|124245039 & Chloroplast HSP70 & 5.18 & 75464.1 & 1050 & 100 & 27 & & 12.82 & $97.76 / 79.11$ \\
\hline 2808 & gil6911551 & Heat shock protein 70 & 5.07 & 71843.3 & 570 & 100 & 25 & & 5.65 & $95.26 / 76.54$ \\
\hline 3101 & gi|255550363 & Groes chaperonin & 8.89 & 26582.2 & 73 & 95.384 & 2 & & 17.20 & $25.06 / 28.38$ \\
\hline 3802 & gi|402753 & Translation elongation factor EF-G & 5.04 & 77865.6 & 89 & 99.894 & 14 & & 5.19 & $92.84 / 99.06$ \\
\hline 4202 & gi|255550363 & Groes chaperonin & 8.89 & 26582.2 & 73 & 95.384 & 2 & & 4.46 & $91.70 / 86.91$ \\
\hline \multicolumn{11}{|c|}{ Peptidase enzymes } \\
\hline 2807 & gi|9759033 & Acyl-peptide hydrolase-like & 5.08 & 76116.9 & 160 & 100 & 10 & & 5.33 & $92.74 / 65.70$ \\
\hline 2905 & gi|297742722 & Oligopeptidase B & 5.21 & 79684.1 & 125 & 100 & 9 & & 2.16 & $68.83 / 56.15$ \\
\hline 3807 & gi|307136309 & Serine-type endopeptidase & 5.15 & 83277.2 & 145 & 100 & 13 & & 2.55 & $84.32 / 37.22$ \\
\hline
\end{tabular}


Table 1 Glucohxaose and ROS modulators-regulated proteins (Continued)

\begin{tabular}{|c|c|c|c|c|c|c|c|c|c|}
\hline 3901 & gi|297742722 & Oligopeptidase B & 5.21 & 79684.1 & 125 & 100 & 9 & 1.55 & $77.53 / 44.01$ \\
\hline 4801 & gi|225468332 & Similar to oligopeptidase A & 5.61 & 58732.5 & 81 & 99.234 & 9 & 2.20 & $99.63 / 62.75$ \\
\hline 4802 & gi|255572579 & Oligopeptidase A, putative & 5.71 & 88118.8 & 129 & 100 & 13 & 2.13 & $99.48 / 44.81$ \\
\hline 4903 & gi|255537515 & Aminopeptidase, putative & 6.04 & 98135.3 & 131 & 100 & 15 & 11.40 & $98.35 / 65.03$ \\
\hline 5902 & gi|255537515 & Aminopeptidase, putative & 6.04 & 98135.3 & 304 & 100 & 15 & 10.90 & $98.02 / 46.32$ \\
\hline 5903 & gi|25083482 & Putative aminopeptidase & 5.43 & 99495.2 & 252 & 100 & 15 & 15.04 & $98.38 / 77.61$ \\
\hline 5904 & gi|255537515 & Aminopeptidase, putative & 6.04 & 98135.3 & 250 & 100 & 18 & 13.49 & $99.19 / 50.26$ \\
\hline \multicolumn{10}{|c|}{ Protein phosphatase } \\
\hline 0303 & gi|15240071 & Putative protein phosphatase $2 \mathrm{C} 80$ & 7.6 & 44302 & 72 & 94.7 & 3 & 2.46 & $29.15 / 49.70$ \\
\hline \multicolumn{10}{|c|}{ Antioxidation proteins } \\
\hline 1402 & gi|18874402 & Galactinol synthase & 4.81 & 38608 & 130 & 100 & 5 & 7.62 & $93.74 / 14.20$ \\
\hline 1802 & gi|11559422 & Disulfide isomerase & 5.07 & 37249 & 589 & 100 & 20 & 3.84 & $89.41 / 74.09$ \\
\hline 1803 & gi|11559422 & Disulfide isomerase & 5.07 & 37249 & 589 & 100 & 20 & 3.38 & $85.47 / 57.64$ \\
\hline 1805 & gi|11559422 & Disulfide isomerase & 5.07 & 37249 & 589 & 100 & 20 & 3.01 & $91.93 / 51.20$ \\
\hline 1806 & gi|11559422 & Disulfide isomerase & 5.07 & 37249 & 589 & 100 & 20 & 3.47 & $94.47 / 68.43$ \\
\hline 2105 & gi|240252434 & NifS-like protein & 6.24 & 67894.1 & 69 & 89.179 & 10 & 4.07 & $11.20 / 34.32$ \\
\hline 2107 & gi|297842615 & Glutathione S-transferase & 5.76 & 75307.3 & 101 & 99.993 & 8 & 2.22 & $67.69 / 9.46$ \\
\hline 3808 & gi|341579690 & Betaine-aldehyde dehydrogenase & 5.25 & 55339.3 & 602 & 100 & 16 & 4.58 & $77.64 / 59.24$ \\
\hline 5804 & gi||124057819 & Raffinose synthase & 5.42 & 87904.5 & 96 & 99.975 & 17 & 391.29 & $99.03 / 60.22$ \\
\hline 7204 & gi||117663160 & Carbonic anhydrase & 6.3 & 10976.5 & 175 & 100 & 5 & 225.27 & $80.50 / 99.93$ \\
\hline 7302 & gi|15222954 & Thioredoxin-like protein CDSP32 & 8.65 & 33948.5 & 253 & 100 & 8 & 1.59 & $26.05 / 52.03$ \\
\hline 8202 & gi||117663160 & Carbonic anhydrase & 6.3 & 10976.5 & 257 & 100 & 7 & 6.96 & $71.19 / 80.24$ \\
\hline \multicolumn{10}{|c|}{ Others } \\
\hline 3803 & gi||224065421 & Peptidylprolyl isomerase & 5.03 & 64379.7 & 105 & 99.997 & 9 & 5.19 & $94.72 / 75.20$ \\
\hline 5703 & gi||108710583 & Adenylosuccinate synthetase & 9.07 & 51473.6 & 247 & 100 & 7 & 3.04 & $70.41 / 61.06$ \\
\hline 5711 & gi|255578102 & $\begin{array}{l}\text { Imidazole glycerol phosphate } \\
\text { synthase subunit hisf }\end{array}$ & 6.62 & 65225.3 & 496 & 100 & 16 & 1.88 & $55.65 / 64.14$ \\
\hline 5803 & gi|9759324 & $\begin{array}{l}\text { 4-hydroxy-3-methylbut-2-en-1-yl } \\
\text { diphosphate synthase }\end{array}$ & 5.89 & 80394.2 & 700 & 100 & 25 & 3.81 & $99.30 / 74.98$ \\
\hline 5812 & gi|225448296 & PREDICTED: hypothetical protein & 6.55 & 106446.4 & 183 & 100 & 10 & 1175.24 & $75.18 / 83.99$ \\
\hline 7406 & gi|18401429 & $\mathrm{N}$-carbamoylputrescine amidase & 5.71 & 33683 & 242 & 100 & 6 & 6.86 & $92.78 / 63.85$ \\
\hline 7606 & gi|255562088 & Transaminase mtnE & 6.95 & 50909.2 & 346 & 100 & 10 & 1.77 & $54.52 / 42.84$ \\
\hline
\end{tabular}


photosynthesis and pentose phosphate pathway proteins, which supplied enough NADPH for generating ROS by NADPH oxidase. An important protein, phosphatase PP2C, was identified in our study. Seventy-six PP2C-type phosphatase candidates were identified in Arabidopsis and divided into 10 groups [26]. The wellstudied PP2C genes, $A B I 1$ and $A B I 2$, are associated with ABA signaling, which involves the closing of stomata by activated $\mathrm{I}_{\mathrm{Ca}} \mathrm{Ca}^{2+}$ Channels induced by ROS [27]. The two genes act differently: abi1-1 interrupted NADPH oxidase-related ROS generation and abi2-1 affected the activation of downstream $\mathrm{I}_{\mathrm{Ca}} \mathrm{Ca}^{2+}$ Channels [28]. In our study, PP2C 80 was identified as a glucohexaose-induced ROS-related protein, which may function either in processes related to ROS generation or in signal output, which should be investigated in a future study.

As ROS are toxic for pathogens and for plants themselves, plants must have antioxidation mechanisms for protecting themselves while still killing the pathogens. In our study, we identified eight antioxidation proteins: galactinol synthase, raffinose synthase, NifS-like protein, thioredoxin-like protein CDSP32, disulfide isomerase, glutathione S-transferase, betaine-aldehyde dehydrogenase and carbonic anhydrase. Galactinol synthase and raffinose synthase are important enzymes for the synthesis of the raffinose family of oligosaccharides, which are important for protecting plants during the stress response [29-31]. Nishizawa et al. found that galactinol and raffinose protected plants from oxidative stress by removing scavenging hydroxyl radicals [30]. The active center of thioredoxins comprises four amino acids, Cys-Gly-Pro-Cys, which can reduce disulfide bridges to protect plants from oxidative damage [32]. We identified a $32 \mathrm{KDa}$ protein thioredoxin, CDSP32. Rey et al. found that the six targets of the overexpression mutants of thioredoxin CDSP32 are involved in a strong resistance to oxidative stress. As a result, compared with other proteins in the thioredoxin family, thioredoxin CDSP32 is presumed to function mainly in antioxidative stress [33]. The reduction of disulfide bridges of thioredoxins is accompanied by an iron-sulfur cluster [34] and another identified protein, NifS-like protein, is important for iron-sulfur cluster synthesis [35]. In addition, the disulfide bridges of thioredoxins are catalyzed by an important chaperone, disulfide isomerase, which was also identified in our research [36]. We identified another three proteins in our research, glutathione-S-transferase, betaine-aldehyde dehydrogenase and carbonic anhydrase. These three are all antioxidative stress proteins, functioning through glutathione [37], betaine [38] and radical scavenging, respectively [39]. These antioxidative stress proteins are further evidence for the induction of ROS accumulation by glucohexaose treatment and may represent the plant protective mechanism induced during oxidative stress.

\section{Discussion}

ROS signaling play an important role in resistance to pathogens as signal molecules in large variety of plant species. In this study, we noticed both $\mathrm{H}_{2} \mathrm{O}_{2}$ and $\mathrm{O}^{2-}$ accumulation in cucumber cotyledons is a part of glucohexaose induced resistance. Normally, there are two phases of ROS accumulation induced by pathogen but only one phase of ROS accumulation induced by elicitors [40]. The glucohexaose elicitor shares similar mechanism with elicitors, which accumulated shortly after treatment and reached the peak level at about $5 \mathrm{~h}$ after treatment. DPI can totally repress the generation of $\mathrm{H}_{2} \mathrm{O}_{2}$ and $\mathrm{O}^{2-}$ and proteomic analysis showed the increasing level of enzymes is relevant to synthesis of NADPH. As a result, the generation of cucumber ROS induced by glucohexaose elicitor is mainly produced by NADPH oxidase. NADPH oxidase appeared from moss and strongly expanded in vascular plants [16]. Our study indicates similar mechanism of ROS generation in cucumber.

We have identified an interesting protein PP2C 80 in our study. It is well known that PP2Cs are important negative regulators in $\mathrm{ABA}$ signaling. $\mathrm{ABA}$ is a hormone involving stress tolerance. ABA can induce stomata closing and ROS generation but NADPH oxidase double mutant atrbohD/F cannot [41]. The activity of two famous PP2Cs ABI1 and ABI2 are repressed by $\mathrm{H}_{2} \mathrm{O}_{2}$ in Arabidopsis [42,43]. In our study, the level of PP2C 80 increased after $\mathrm{H}_{2} \mathrm{O}_{2}$ accumulation. We have no idea whether the PP2C is involved in ABA signaling and why it accumulate after $\mathrm{H}_{2} \mathrm{O}_{2}$ accumulation. But it is an indication that glucohexaose induced resistance may have relationship with ABA signaling.

The identification of thioredoxin could contribute to the regulation of ROS level. Scavengers glutathioneS-transferase, betaine-aldehyde dehydrogenase and carbonic anhydrase are increased after gluchexaose treatment. Thioredoxin also increase after ROS accumulation in Arabidopsis, soybeans and potatoes [44-46]. Our study showed similar mechanism in cucumber. Meanwhile, SOD, POD and APX activities are increased in our study. The scavengers of ROS may function after ROS accumulation to prevent further damage to plant cells. We also found scavengers CAT and GPX decreased after glucohexaose treatment. They may have functions in ROS accumulation.

\section{Concluding remarks}

Our study detected the accumulation of ROS is a part of mechanism of glucohexaose induced resistance in cucumber cotyledons. NADPH oxidase is in charge of the main generation of the rapidly output of ROS. ROS scavengers' activities change in the progress to regulate ROS level. Thirty-seven up-regulate proteins were identified after glucohexaose treatment and repressed 
by DPI, which are involved in photosynthesis, respiration, translation, phosphorylation and antioxidation. PP2C might play a crucial role in processes related to ROS generation and signal transduction, and antioxidation proteins increased after glucohexaose treatment, indicating the involvement of a self-protection mechanism in the process. It will be interesting to find out the regulatory mechanism underlying the induction of ROS-targeting proteins via ROS, and provide clues concerning the mechanism of glucohexaose-induced resistance and a theoretical basis for developing safe farm chemicals for vegetable production.

\section{Additional file}

Additional file 1: Figure S1. 2D maps of cucumber cotyledon proteins with different treatment and the spots identified. A, Control group, fraction F1; B, the cucumber cotyledons treated with $50 \mathrm{\mu g} / \mathrm{mL}$ glucohexaose for five hours, fraction F1; C, Before treated with $50 \mu \mathrm{g} / \mathrm{mL}$ glucohexaose, DPI were incubated for four hours, fraction F1; D, Before treated with $50 \mu \mathrm{g} / \mathrm{mL}$ glucohexaose, DMTU were incubated for four hours, fraction F1; $\mathbf{E}$, Control group, fraction F2; $\mathbf{F}$, the cucumber cotyledons treated with $50 \mathrm{\mu g} / \mathrm{mL}$ glucohexaose for five hours, fraction F2; G, Before treated with $50 \mu \mathrm{g} / \mathrm{mL}$ glucohexaose, DPI were incubated for four hours, fraction $\mathrm{F} 2 ; \mathbf{H}$, Before treated with $50 \mu \mathrm{g} / \mathrm{mL}$ glucohexaose, DMTU were incubated for four hours, fraction F2. Figure S2. Differential protein spots and their relative abundance. All identified protein spots' Representative differential protein spots and their relative abundance information.

\section{Abbreviations}

$\mathrm{H}_{2} \mathrm{O}_{2}$ : Hydrogen peroxide; $\mathrm{O}^{2-}$ : Superoxide; DPI: Diphenyleneiodonium chloride; DMTU: Dimethylthiourea; SOD: Superoxide dismutase; CAT: Catalase; APX: Ascorbate peroxidase; GPX: Glutathione peroxidase;

MDA: Malonaldehyde; POD: Peroxidase; DAB: Diaminobenzidine; ABA: Abscisic acid; SA: Salicylic acid; JA: Jasmonic acid; TCA: Trichloroacetic acid; TBP: Tributyl phosphate; P6: Glucohexaose.

\section{Competing interests}

The authors declare that they have no competing interests.

\section{Authors' contributions}

$\mathrm{HF}$ is responsible for experimental design and manuscript revising. YH measured the $\mathrm{H}_{2} \mathrm{O}_{2}$ and $\mathrm{O}^{2-}$ contents; run the $2 \mathrm{D}$ gels; analyzed $2 \mathrm{D}$ image and MS data. NL and CL measured the contents of scavenger enzymes activity. YY and SC is responsible for mass spectrometry analysis. All authors read and approved the final manuscript.

\section{Acknowledgements}

All the authors thank Prof. J Ning for providing glucohexaose, Dr. Haijiao Wang for revising this paper and Shanghai Applied Protein Technology Co. Ltd for protein identification with MALDI-TOF-TOF MS. At last, thank all my friends who have given us so much help

\section{Author details}

${ }^{1}$ College of Bioscience and Biotechnology, Shenyang Agricultural University, Shenyang 110866 , PR China. ${ }^{2}$ Key Laboratory of Protected Horticulture of Ministry of Education, Shenyang Agricultural University, Shenyang 110866, PR China. ${ }^{3}$ State Key Laboratory of Genetic Engineering and Institute of Plant Biology, School of Life Sciences, Fudan University, Shanghai 200433, PR China. ${ }^{4}$ Fruit and Silkworm Administrative Station of Liaoning Province, Shenyang 110866, PR China.

Received: 17 January 2014 Accepted: 1 May 2014

Published: 17 June 2014

\section{References}

1. Haiyan F, Baojv L, Chunmao L, Tianlai L, Baoli Z: Study on cucumber plant resistance introduced by glucohexaise against Pseudoperonospora cubensis disease. Plant Prot 2003, 29:14-16.

2. YuHan H, ChunFei W, DaWei Z, LeeNa T, Yang Y: Proteomic analysis of glucohexaoseinducedresistancetodowny mildew in Cucumis sativus. Aust J Crop Sci 2013, 7:1242-1251.

3. Lamb C, Dixon RA: The oxidative burst in plant disease resistance. Annu Rev Plant Physiol Plant Mol Biol 1997, 48:251-275.

4. Doke N: Involvement of superoxide anion generation in the hypersensitive response of potato tuber tissues to infection with an incompatible race of Phytophthora infestans and to the hyphal wall components. Plant Pathol Lab 1983, 23:345-357.

5. Averyanov A: Oxidative burst and plant disease resistance. Front Biosci (Elite Ed) 2009, 1:142-152

6. Orozco-Cardenas M, Ryan CA: Hydrogen peroxide is generated systemically in plant leaves by wounding and systemin via the octadecanoid pathway. Proc Natl Acad Sci U S A 1999, 96:6553-6557.

7. Wojtaszek P: Oxidative burst: an early plant response to pathogen infection. Biochem J 1997, 322(Pt 3):681-692.

8. Neill S, Desikan R, Hancock J: Hydrogen peroxide signalling. Curr Opin Plant Biol 2002, 5:388-395.

9. Moller IM, Sweetlove L: ROS signalling-specificity is required. Trends Plant Sci 2010, 15:370-374

10. Bolwell GP, Davies DR, Gerrish C, Auh CK, Murphy TM: Comparative biochemistry of the oxidative burst produced by rose and french bean cells reveals two distinct mechanisms. Plant Physiol 1998, 116:1379-1385.

11. Papadakis AK, Roubelakis-Angelakis KA: The generation of active oxygen species differs in tobacco and grapevine mesophyll protoplasts. Plant Physiol 1999, 121:197-206.

12. Berna A, Bernier F: Regulation by biotic and abiotic stress of a wheat germin gene encoding oxalate oxidase, a $\mathrm{H} 2 \mathrm{O} 2$-producing enzyme. Plant Mol Biol 1999, 39:539-549.

13. Yoda H, Hiroi Y, Sano H: Polyamine oxidase is one of the key elements for oxidative burst to induce programmed cell death in tobacco cultured cells. Plant Physiol 2006, 142:193-206.

14. Bindschedler LV, Dewdney J, Blee KA, Stone JM, Asai T, Plotnikov J, Denoux C, Hayes T, Gerrish C, Davies DR, Ausubel FM, Bolwell GP: Peroxidasedependent apoplastic oxidative burst in Arabidopsis required for pathogen resistance. Plant J 2006, 47:851-863.

15. Daudi A, Cheng Z, O'Brien JA, Mammarella N, Khan S, Ausubel FM, Bolwell GP: The apoplastic oxidative burst peroxidase in Arabidopsis is a major component of pattern-triggered immunity. Plant Cell 2012, 24:275-287.

16. Mittler R, Vanderauwera S, Suzuki N, Miller G, Tognetti VB, Vandepoele $K$, Gollery M, Shulaev V, Breusegem FV: ROS signaling: the new wave? Trends Plant Sci 2011, 16:300-309.

17. Nanda AK, Andrio E, Marino D, Pauly N, Dunand C: Reactive oxygen species during plant-microorganism early interactions. I Integr Plant Biol 2010, 52:195-204.

18. Scheler C, Durner J, Astier J: Nitric oxide and reactive oxygen species in plant biotic interactions. Curr Opin Plant Biol 2013, 16:534-539.

19. Soares NC, Wojtkowska J, Jackson PA: A proteomic analysis of the wound response in Medicago leaves reveals the early activation of a ROS-sensitive signal pathway. J Proteomics 2011, 74:1411-1420.

20. Wang H, Wang S, Lu Y, Alvarez S, Hicks LM, Ge X, Xia Y: Proteomic analysis of early-responsive redox-sensitive proteins in arabidopsis. J Proteome Res 2012, 11:412-424.

21. Bykova NV, Hoehn B, Rampitsch C, Banks T, Stebbing JA, Fan T, Knox R: Redox-sensitive proteome and antioxidant strategies in wheat seed dormancy control. Proteomics 2011, 11:865-882.

22. Zhang $X$, Wang $P$, Song C: Methods of detecting hydrogen peroxide in plant cells. Chin Bull Bot 2009, 44:103-106.

23. Xi J, Wang X, Li S, Zhou X, Yue L, Fan J, Hao D: Polyethylene glycol fractionation improved detection of low-abundant proteins by two-dimensional electrophoresis analysis of plant proteome. Phytochemistry 2006, 67:2341-2348.

24. Pugin A, Frachisse JM, Tavernier E, Bligny R, Gout E, Douce R, Guern J: Early events induced by the elicitor cryptogein in tobacco cells: involvement of a plasma membrane NADPH oxidase and activation of glycolysis and the pentose phosphate pathway. The Plant Cell Online 1997, 9:2077-2091. 
25. Kruger NJ, von Schaewen A: The oxidative pentose phosphate pathway: structure and organisation. Curr Opin Plant Biol 2003, 6:236-246.

26. Schweighofer A, Hirt H, Meskiene I: Plant PP2C phosphatases: emerging functions in stress signaling. Trends Plant Sci 2004, 9:236-243.

27. Ma Y, Szostkiewicz I, Korte A, Moes D, Yang Y, Christmann A, Grill E: Regulators of PP2C phosphatase activity function as abscisic acid sensors. Science 2009, 324:1064-1068.

28. Murata Y, Pei Z-M, Mori IC, Schroeder J: Abscisic acid activation of plasma membrane $\mathrm{Ca} 2+$ channels in guard cells requires cytosolic $\mathrm{NAD}(\mathrm{P}) \mathrm{H}$ and is differentially disrupted upstream and downstream of reactive oxygen species production in abi1-1 and abi2-1 protein phosphatase $2 \mathrm{C}$ mutants. Plant Cell Online 2001, 13:2513-2523.

29. Wang Z, Zhu Y, Wang L, Liu X, Liu Y, Phillips J, Deng X: A WRKY transcription factor participates in dehydration tolerance in Boea hygrometrica by binding to the W-box elements of the galactinol synthase (BhGolS1) promoter. Planta 2009, 230:1155-1166.

30. Nishizawa A, Yabuta Y, Shigeoka S: Galactinol and raffinose constitute a novel function to protect plants from oxidative damage. Plant Physiol 2008, 147:1251-1263.

31. Zhao TY, Thacker R, Corum JW III, Snyder JC, Meeley RB, Obendorf RL, Downie B: Expression of the maize GALACTINOL SYNTHASE gene family: (I) Expression of two different genes during seed development and germination. Physiol Plant 2004, 121:634-646.

32. Eklund $\mathrm{H}$, Gleason FK, Holmgren A: Structural and functional relations among thioredoxins of different species. Proteins: Struct Funct Bioinform 1991, 11:13-28.

33. Rey P, Cuine S, Eymery F, Garin J, Court M, Jacquot JP, Rouhier N, Broin M: Analysis of the proteins targeted by CDSP32, a plastidic thioredoxin participating in oxidative stress responses. Plant J 2005, 41:31-42.

34. Schurmann P: Redox signaling in the chloroplast: the ferredoxin/ thioredoxin system. Antioxid Redox Signal 2003, 5:69-78.

35. Ye H, Garifullina GF, Abdel-Ghany SE, Zhang L, Pilon-Smits EA, Pilon M: The chloroplast NifS-like protein of Arabidopsis thaliana is required for iron-sulfur cluster formation in ferredoxin. Planta 2005, 220:602-608.

36. Gruber CW, Cemazar M, Heras B, Martin JL, Craik DJ: Protein disulfide isomerase: the structure of oxidative folding. Trends Biochem Sci 2006, 31:455-464.

37. Öztetik E: A tale of plant glutathione S-transferases: since 1970. Bot Rev 2008, 74:419-437.

38. Rosas-Rodriguez JA, Valenzuela-Soto EM: Inactivation of porcine kidney betaine aldehyde dehydrogenase by hydrogen peroxide. Chem Biol Interact 2011, 191:159-164.

39. Deepak SA, Shibato J, Ishii H, Ogawa Y, Yoshida Y, Iwahashi H, Masuo Y, Agrawal GK, Rakwal R: Proteomics approach for investigating the disease resistance using cucumber as model plant. Am J Biochem Biotechnol 2008, 4:231-238.

40. De Gara L, de Pinto MC, Tommasi F: The antioxidant systems vis-à-vis reactive oxygen species during plant-pathogen interaction. Plant Physiol Biochem 2003, 41:863-870.

41. Kwak JM, Mori IC, Pei ZM, Leonhardt N, Torres MA, Dangl JL, Bloom RE, Bodde S, Jones JD, Schroeder Jl: NADPH oxidase AtrbohD and AtrbohF genes function in ROS-dependent ABA signaling in Arabidopsis. EMBO 2003, 22:2623-2633.

42. Meinhard M, Grill E: Hydrogen peroxide is a regulator of $A B I 1$, a protein phosphatase 2C from Arabidopsis. FEBS Lett 2001, 508:443-446.

43. Meinhard M, Rodriguez PL, Grill E: The sensitivity of ABI2 to hydrogen peroxide links the abscisic acid-response regulator to redox signalling. Planta 2002, 214:775-782.

44. Laloi C, Mestres-Ortega D, Marco Y, Meyer Y, Reichheld JP: The Arabidopsis cytosolic thioredoxin $\mathrm{h} 5$ gene induction by oxidative stress and its W-box-mediated response to pathogen elicitor. Plant Physiol 2004, 134:1006-1016.
45. Lee MY, Shin KH, Kim YK, Suh JY, Gu YY, Kim MR, Hur YS, Son O, Kim JS, Song E, Lee MS, Nam KH, Hwang KH, Sung MK, Kim HJ, Chun JY, Park M, Ahn TI, Hong CB, Lee SH, Park HJ, Park JS, Verma DP, Cheon Cl: Induction of thioredoxin is required for nodule development to reduce reactive oxygen species levels in soybean roots. Plant Physiol 2005, 139:1881-1889.

46. Vieira Dos Santos C, Rey P: Plant thioredoxins are key actors in the oxidative stress response. Trends Plant Sci 2006, 11:329-334.

doi:10.1186/1477-5956-12-34

Cite this article as: Hao et al:: Proteomic analysis of Cucumis sativus cotyledons after glucohexaose treatment as a part of ROS accumulation related resistance mechanism. Proteome Science 2014 12:34.

\section{Submit your next manuscript to BioMed Central and take full advantage of:}

- Convenient online submission

- Thorough peer review

- No space constraints or color figure charges

- Immediate publication on acceptance

- Inclusion in PubMed, CAS, Scopus and Google Scholar

- Research which is freely available for redistribution 